\title{
Abela and Others v Baadarani: The Politics Within the Supreme Court
}

\author{
Dorota Galeza 1
}

Published online: 9 June 2016

(C) The Author(s) 2016. This article is published with open access at Springerlink.com

\begin{abstract}
The Supreme Court deals with many political cases, where policies are at stake, while on the other hand there is the politics within the Court which can also play an important role. It is difficult to judge the current system without sound empirical and theoretical studies, so one cannot confidently assess the effectiveness of the paper appeals in the American System in the light of the long history of the UK system, of different career paths of advocates in these two countries and of different routes of appointment for judges in both jurisdictions. Nevertheless, any interviews that were conducted with senior judges in the UK were conducted a long time ago and might not be applicable to the current realities. It is true that the British system is open to moderation - the elimination of the House of Lords and its replacement with the Supreme Court is the best example-but maybe more changes are needed. It is paramount that greater diversity in the profession brings fresh perspectives. This is evident in electing practitioners with different career paths, such as Justice Kennedy and Lord Sumption. The president of the Supreme Court, Lord Neuberger, even suggested advertising the next position in the Supreme Court to be on a part time basis, to enable the election of an academic. As stated in the introduction, since Abela and others $\mathrm{v}$ Baadarani is a case with important principles at stake, is there a space for political disagreement?
\end{abstract}

Keywords Procedure $\cdot$ Commercial law $\cdot$ Politics

Dorota Galeza

Dorota.galeza@postgrad.manchester.ac.uk

1 Law School, Manchester University, Oxford Road, Manchester M13 9PL, UK 


\section{Introduction}

Abela and others $v$ Baadarani [2013] UKSC 44 could be considered as an interesting judgment because of the principles established in it. In this case, the Supreme Court provided important guidance on the interpretation and application of rule 6.15(1) and (2). "Where it can be shown, as here, that the defendant is well aware of the proceedings and the nature of the claims made, the court will not look kindly on 'technical games'.... [Nevertheless], alternative retrospective service is not without its dangers, particularly where the claim is commenced near the end of the limitation period or enforcement overseas will be necessary." 1

However, this article argues that the case can be noteworthy due to the politics within the courts and the tactics that can sometimes be adopted by certain Supreme Court judges to encourage a shift in opinion that can lead to a switch in votes or even to a reversal of the existing majority position. In this case an equal number of Supreme Court judges agreed with the dissent and with the leading judgment, i.e. Lord Neuberger, Lord Reed and Lord Carnwath agreed with both Lord Clarke, proving the judgment of the court, and Lord Sumption, providing the dissenting judgment.

\section{Analysis}

\section{The UK and Abela and Others $v$ Baadarani}

The Supreme Court remains a political court and, as long as various problems are a matter of national policy (abortion, secular marriages and civil partnerships), many issues should be dealt with by a careful analysis of precedents and established principles.

In this jurisdiction, successes such as Abela and others $v$ Baadarani can occur but are hardly ever documented. It is argued that something of this nature took place in this case, as the dissenting judgment to some extent "overshadowed" the majority judgment.

This article also proposes that this case is a great example of personality mattering when it comes to adjudication. The article takes a position that Lord Sumption is a very interesting persona in the Supreme Court, as his background and experience is different. He is the only judge in the Supreme Court who was promoted to this position without being a full time judge at all. Beyond that, he is an excellent practitioner, with many accomplishments, such as the fact that he received the highest fee in British legal history (Abramovich v Berezovsky). ${ }^{2}$ Interestingly, he is also an accomplished historian. ${ }^{3}$ His promotion resembles the appointment by

\footnotetext{
${ }^{1}$ http://hsfnotes.com/litigation/2013/06/27/uk-supreme-court-clarifies-when-retrospective-alternativeservice-out-of-the-jurisdiction-is-permitted/ (last accessed 29/07/2015).

2 http://www.thesundaytimes.co.uk/sto/news/uk_news/Society/article1121765.ece (last accessed 28/07/ 2015).

3 http://www.faber.co.uk/tutors/jonathan-sumption/ (last accessed 28/07/2015).
} 
the US President of Justice Kennedy, who was also raised to the US Supreme Court from private practice. ${ }^{4}$

Abela and others $v$ Baadarani is an example in which the final judgment cannot be taken at face value. However, there is little empirical research in this area. The most comprehensible study was conducted by Paterson. However, the interviews with Law Lords were conducted mainly during the Bingham era (Paterson 2013, 177). Therefore, it might be the case that they are a bit dated.

Paterson provided some starting points on what actually happens in the judges' room. According to Paterson, most changes take place during the hearing stage, but they can also occur between the first conference and the final judgment. Therefore, it is not only about how thoroughly a case is presented, but oral submissions really matter (Paterson 2013, 207). This article argues that this is surprising, taking into account the extent to which Supreme Court judges are established members of the profession. Similarly to judges in the US, they have access to independent researchers-judicial assistants. Nevertheless, in the UK, the assistants' role in the drafting of the judgment is limited. They merely assist with the legal research (Nesterchuk 2013). It is important to note that any empirical studies that led to this judgment were conducted in slightly different settings. Nevertheless, it can be concluded that there is little difference between the position under the House of Lords and the Supreme Court. ${ }^{5}$

\section{The US}

The US developed a different system of electing judges. In the US, federal court judges are appointed by the President whereas, in many states, judges are elected in judicial retention referendums, conducted on a similar basis to general elections. ${ }^{6}$ There is a vast literature on the behaviour of judges in higher courts in the US, ${ }^{7}$ but it is uncertain whether this literature could be transposed to the UK. For instance, Epstein, Landes and Posner are correct in stating that judges can be influenced by personalities and leisure preferences, (Epstein et al. 2013) but it is uncertain how the American system, with a vast majority of paper appeals, ${ }^{8}$ would work in the UK. The UK model has a tradition of excellent advocacy ${ }^{9}$ and it is evident from Paterson's study that the hearing stage is the most influential as far as the position of the judges is concerned.

\footnotetext{
${ }^{4}$ http://www.theguardian.com/us-news/2015/jun/26/kennedy-ruling-gay-marriage-supreme-court (last accessed 28/07/2015).

5 See (Paterson 2013) Final judgment the last law lords and the Supreme Court, Oup, Oxford, p. 207; (Epstein et al. 2013); (Posner 1997-1998); (Cohen and Spitzer 1995-1996; (Cross and Tiller 1998).

${ }^{6}$ http://www.judicialselection.us/ (last accessed 28/07/2015); http://www.justiceatstake.org/issues/state_ court_issues/election-vs-appointment/ (last accessed 28/07/2015); http://litigation.findlaw.com/legalsystem/how-are-judges-selected.html (last accessed 28/07/2015).

7 See (Niblett et al. 2008).

8 'fewer than $25 \%$ of briefed cases overall are given oral argument, the brief may be your only chance to argue your position.' http://www.ca5.uscourts.gov/clerk/docs/pracguide.pdf (last accessed 28/07/2015).

9 http://www.theguardian.com/law/2011/mar/02/queens-counsel-appointments (last accessed 28/07/ 2015).
} 


\section{The Comparison}

There are powerful voices for both systems. The American Supreme Court appears to be based on more sound theoretical principles (a vast majority of paper appeals), but the system is not free from controversial decisions, such as Leegin Creative Leather Products, Inc. v. PSKS, Inc. 551 US 877, where the US Supreme Court overruled a nearly 100-year old precedent. ${ }^{10}$ Nota bene, the majority judgment was decided by Justice Kennedy who, similarly to Lord Sumption, was appointed straight from practice. Debatable rulings are not alien to the UK system, where some judgments, for instance, appear to be inconsistent with the precedents of the European Court of Justice (now the Court of Justice). ${ }^{11}$ It can also be argued that there is much discrimination within the profession. ${ }^{12}$ Nevertheless, with the career system of advocates' progression and promotions to the Queen's Counsels of the most established practitioners of the Bar, (Maute 2002-2003) the system is home to the best legal practitioners in the world.

\section{Conclusions}

The Supreme Court deals with many political cases, where policies are at stake, while on the other hand there is the politics within the Court which can also play an important role. It is difficult to judge the current system without sound empirical and theoretical studies, so one cannot confidently assess the effectiveness of the paper appeals in the American System in the light of the long history of the UK system, of different career paths of advocates in these two countries and of different routes of appointment for judges in both jurisdictions. Nevertheless, any interviews that were conducted with senior judges in the UK were conducted a long time ago and might not be applicable to the current realities. It is true that the British system is open to moderation-the elimination of the House of Lords and its replacement with the Supreme Court is the best example ${ }^{13}$-but maybe more changes are needed. It is paramount that greater diversity in the profession brings fresh perspectives. This is evident in electing practitioners with different career paths, such as Justice Kennedy and Lord Sumption. The president of the Supreme Court, Lord Neuberger, even suggested advertising the next position in the Supreme Court to be on a part time basis, to enable the election of an academic. ${ }^{14}$

\footnotetext{
${ }^{10}$ Dr. Miles Medical Co. v. John D. Park \& Sons Co., 220 U.S. 373, (1991).

11 Duke v Reliance Systems Ltd., [1989] 1 A.C. 76, [1988] 3 C.M.L.R. 221; Case C-108/89 Marleasing SA v La Comercial Internacional de Alimentacion SA, [1990] ECR I-4135; Hodgson (1994) How English Judges Get European Law Wrong, 3 Nottingham L. J. 34.

12 http://www.theguardian.com/law/2011/sep/01/disabled-lawyers-still-face-discrimination (last accessed 28/07/2015); http://www.globaljusticeblog.ed.ac.uk/2013/04/24/discrimination-against-women-inlaw/ (last accessed 28/07/2015); http://www.genderforum.org/print/issues/working-out-gender/ discrimination-against-women-lawyers-in-england-and-wales/?print=1 (last accessed 28/07/2008).

13 http://www.publications.parliament.uk/pa/ld200304/ldselect/ldcref/125/12505.htm (last accessed 28/07/2015).

14 Lord Neuberger's lecture on access to justice, social mobility in the legal profession and the role of the Supreme Court, 8 May 2014, Manchester University.
} 
As stated in the introduction, since Abela and others $v$ Baadarani is a case with important principles at stake, is there a space for political disagreement?

Open Access This article is distributed under the terms of the Creative Commons Attribution 4.0 International License (http://creativecommons.org/licenses/by/4.0/), which permits unrestricted use, distribution, and reproduction in any medium, provided you give appropriate credit to the original author(s) and the source, provide a link to the Creative Commons license, and indicate if changes were made.

\section{References}

Cohen, Linda R. and Matthew L. Spitzer. 1995-1996. Judicial deference to agency action: A rational choice theory and an empirical test symposium on positive political theory and law: Part two. Southern California Law Review 69:431.

Cross, Frank B., and Emerson H. Tiller. 1998. Judicial partisanship and obedience to legal doctrine: Whistleblowing on the federal courts of appeals. Yale Law Journal 107(7): 2155.

Epstein, Lee, William M. Landes, and Richard A. Posner. 2013. The behaviour of federal judges: A theoretical and empirical study of rational choice. Cambridge: Harvard Law Review.

Hodgson, John. 1994. How English judges get European law wrong. Nottingham Law Journal 3: 34.

Maute, Judith L. 2002-2003. Alice's adventures in wonderland: Preliminary reflections on the history of the split English legal profession and the fusion debate (1000-1900 A.D.) symposium: The legal profession: Looking backward. Fordham Law Review 71:1357.

Nesterchuk, Tatyana. 2013. The view from behind the bench: The role of judicial assistants in the UK Supreme Court. In Judge and jurist: Essays in memory of Lord Rodger of Earlsferry, ed. A. Burrows, D. Johnson, and R. Zimmermann. Oxford: OUP.

Niblett, Anthony, Richard Posner and Andrei Shleifer. 2008. The evolution of a legal rule. NBER Working Paper Series, Working Paper 13856. http://www.nber.org/papers/w13856. 22 Feb 2012.

Paterson, Alan. 2013. Final judgment the last law lords and the Supreme Court. Oxford: OUP.

Posner, Richard A. 1997-1998. Rational choice, behaviour economics, and the law. Stanford Law Review 50:1551.

\section{Cases citied}

Abela and others v Baadarani [2013] UKSC 44.

Dr. Miles Medical Co. v. John D. Park \& Sons Co., 220 U.S. 373, (1991).

Duke v Reliance Systems Ltd., [1989] 1 A.C. 76, [1988] 3 C.M.L.R. 221; Case C-108/89 Marleasing SA v La Comercial Internacional de Alimentacion SA, [1990] ECR I-4135.

Leegin Creative Leather Products, Inc. v. PSKS, Inc. 551 US 877.

\section{Websites}

http://www.publications.parliament.uk/pa/ld200304/ldselect/ldcref/125/12505.htm. Accessed 28 July 2015.

http://www.ca5.uscourts.gov/clerk/docs/pracguide.pdf. Accessed 28 July 2015.

http://www.thesundaytimes.co.uk/sto/news/uk_news/Society/article1121765.ece. Accessed 28 July 2015. http://www.faber.co.uk/tutors/jonathan-sumption/. Accessed 28 July 2015.

http://www.theguardian.com/law/2011/mar/02/queens-counsel-appointments. Accessed 28 July 2015. http://www.theguardian.com/law/2011/sep/01/disabled-lawyers-still-face-discrimination. Accessed 28 July 2015; http://www.globaljusticeblog.ed.ac.uk/2013/04/24/discrimination-against-women-in-law/. Accessed 28 July 2015; http://www.genderforum.org/print/issues/working-out-gender/ discrimination-against-women-lawyers-in-england-and-wales/?print=1. Accessed 28 July 2008.

http://hsfnotes.com/litigation/2013/06/27/uk-supreme-court-clarifies-when-retrospective-alternative-serv ice-out-of-the-jurisdiction-is-permitted/. Accessed 29 July 2015. 
http://www.theguardian.com/us-news/2015/jun/26/kennedy-ruling-gay-marriage-supreme-court. Accessed 28 July 2015.

http://www.judicialselection.us/. Accessed 28 July 2015; http://www.justiceatstake.org/issues/state_ court_issues/election-vs-appointment/. Accessed 28 July 2015; http://litigation.findlaw.com/legalsystem/how-are-judges-selected.html. Accessed 28 July 2015.

\section{Lectures}

Lord Neuberger's lecture on access to justice, social mobility in the legal profession and the role of the Supreme Court, 8 May 2014, Manchester University. 